\title{
PSYCHOLOGY OF LANGUAGE LEARNING - MOTIVATION AND LANGUAGE IDENTITY
}

\author{
Liliya Doncheva \\ NSA "Vassil Levski”, Sofia
}

\begin{abstract}
Introduction: The influence of globalization and the dominant role of English as lingua franca have provoked a critical discussion about the role of motivation in language acquisition in the recent years (Crystal, 2003; Jenkins, 2007). The traditional concept of integrative motivation (Gardner, Lambert, 1972) which is identification and willingness to integrate in the target language community has started losing its explanatory power (Mcdonough, 1981; Clement, Kruidenier, 1983; Doncheva, 2012). Nowadays English language has become an obligatory education skill and a must along the path of one's professional realization. Moreover, there is no explicitly geographically defined English speaking community since the physical geographical borders dividing the different language users have become dissolved in the world of cyber-space and online telecommunication networks (Graddol, 2006). The computers and the internet change really quickly the abilities and skills needed to achieve success in one's studies and job (Dimitrova, 2006). Consequently, the concept of motivation is being rebuilt in the context of the modern theories of the development of Self and identity in the global society - what people believe they are, how they interact with the others and what they would like to become in the future. In the last few years there have been a lot of surveys on the validity of the construct of possible Selves and their connection with the motivation for language studies (Csizér \& Kormos, 2009; Ryan, 2009; Taguchi, Magid \& Papi, 2009). The focus has been shifted from achievement motivation to motivation oriented toward identity (Dörnyei, Csizér, Németh, 2006). L2 motivation is connected with the objectives of one's identity which are valued by the person and reflect the way one's Self corresponds to the surrounding world (van Lier, 2007).

The idea of Self and identity plays an important role in the way teachers engage their students' motivation, interests and identities in their classes. It also explains why digital technologies, social networks and online communication should be implemented in the teaching process (Kuleva, 2014).
\end{abstract}

Purpose and objectives of the study: The aim of the report is to make a brief review of the literature and the views of the authors from 1972 to present days and to outline some of the contributing factors which affect the development of "language self" and different identity in the process of foreign language acquisition.

Methodology: The survey is based on a systematic-structure and psychological analysis of the literature on the subject. A comparative analysis of the concepts of the different authors was made, and their critical opinions were presented together with the personal views and observations of the author based on her experience with Bulgarian students.

Results: It is important to point out that language is a means of self-expression and a way of conveying and constructing of what we are and what our attitude to the world around us is, i.e. to state our Self and our identity before the others.

Because of the strong connection between self-expression through language and self-perception of an individual, Guiora (1972) talks about the existence of a different Self in the process of foreign language learning which is called a "language ego". It is based on the psychic experience shared by lots of people who study a foreign language that a person feels as a different individual when conversing in foreign language and very often acts in a different way in identical situations (Guiora \& Acton, 1979). According to Guiora (1972) foreign language acquisition requires that the individual obtain a new identity which is easier for some people and harder for others.

Rardin (1988) develops further this idea, suggesting that foreign language learning may produce an existential anxiety in learners. They are likely to develop the apprehension that by learning a different language they will lose themselves in one way or another "I, the way I know myself, will cease to exist". In other words, learning a foreign language "affects the essence of identity and self-perception of an individual".

In 1986 Markus and Nurius developed their theory 
of the possible future Selves (Markus, Nurius, 1986) which is based on the individuals' ideas of what they may become, what they would like to become and what they fear to become. The possible future Selves function as guidelines and direct the motivated behavior, i.e. this is the connection between Self-concept and motivation. But not all possible future Selves affect motivation. Those which represent the ideal Self are more likely to do it because of our psychological desire to reduce the discrepancy between our current Self and the ideal Self. This is the main principle which lies in Higgins's theory (1987) of self-discrepancy and self-regulation.

On this base Dörnyei $(2005,2009)$ derives the two key constructs in his new motivation system, based on possible Selves: ideal L2 Self and ought-to L2 self. The first one represents the attributions the individual wishes to possess in order to meet the expectations and society pressure and to avoid negative consequences. The ought-to self refers to outer kinds of instrumental motives with preventive focus (e.g. to study hard to pass an exam, to meet your parents' expectations, etc.). Unlike it, the ideal Self has a promotion focus and the motivation is shaped by the desired image we want to obtain in social, personal and professional context when using the foreign language. Dörnyei's model also includes the experiences during the process of foreign language acquisition which shape the everyday motivation of learners. They are based to a very large extend on the teacher's influence and the education environment (Dörnyei, Csizér \& Németh, 2006).

The possible Language Selves which represent imaginary future identities and may direct motivation include present identities and future objectives. While some of the identities are relatively stable, others are likely to be in a constant process of construction through our interactions with the others and because of our constantly changing relations with the world and our experiences. This fact places our current experiences in the center of our motivation to learn a language along with the objectives of the identity and future aspirations. If we want learners to visualize themselves as competent foreign language users in the future and to construct their ideal Self, they must be able to engage their current Selves and identity in their interactions when using the foreign language. In this way, they will have the possibility to engage their possible future Selves as foreign language users but within the boundaries and the security of their current communicative abilities, interests and social context (Ushioda, 2009). This means that the way we engage students' social identities during their interactions in the foreign language in the classroom and outside it has important consequences on the way they visualize themselves as future users of the foreign language.

The foreign language is not simply something we add to our abilities, but a personalized instrument which enables us to extend and express our identity or our idea of Self in new and interesting ways with new people, to broaden our horizon, to gain access to new and alternative sources of information, entertainment and materials which we need, value or like.

From pedagogical point of view this means we should encourage our students to view the foreign language as a means of self-expression and self-development. In other words we have to engage their own identities and interest in the lessons and to ensure continuity of what they study in the classroom and what they are and are interested in outside it. Thus, as Little (2004) says, "what they learn becomes part of what they are".

These ideas were implemented in the new Dogme Language Teaching Method developed a few years ago (Thornbury, 2000; Meddings \& Thornbury, 2009), which emphasizes on the dialogue interaction between the lecturer and the learners. Communication is authentic and initiated by the students, not contrived and controlled by the teacher. The choice of curriculum and materials is shaped regarding students' interests and the acquisition of language rules is done on the base of dialogues. The three principles of Dogme - conversation driven curriculum, light materials and focus on emergent language represent a new way of teaching and a new way of being a teacher. The focus in the classroom is on self-expression and identity of the learners.

Richards (2006) surveys whether "real" conversations are possible in the classroom. In this connection he distinguishes three aspects of identity: 1) situated identities, which arise from the context of communication, e.g. doctor/patient, student/teacher; 2) discourse identities when the participants are oriented towards particular roles in the interaction, e.g. initiator of the conversation, listener, asking questions; 3) transportable identities which are la- 
tent or implicit but could be expressed in the interaction, e.g. when the teacher mentions her role as a mother or a keen gardener during the lesson.

The implementation of this method in the language classes of sports students shows very convincingly the powerful motivation influence of provoking their situated, discourse, and transportable identities. Engaging students' transportable identities (e.g. football fans, coaches, players, referees) leads to a higher level of personal involvement and participation. The curriculum organized around practical discourse and topics that the students find interesting and relevant to their own experiences improve their motivation to actively take part in the English classes. By provoking learners' situated and discourse identities the teacher may encourage a greater investment of efforts on behalf of the learners. Students believe the material is useful for them and even those who have basic knowledge of the language feel less apprehensive to communicate. The fact they have to use emergent language rather than draw upon strict preliminarily taught grammar and syntax rules places them in the role of generators of the lesson. This is very different from the regular situation where they are in the position of foreign language learners who just practice or demonstrate knowledge and do not express their own voice or identity through it.

Conclusions: The overall review of the literature and the conclusions drawn emphasize on the necessity of further studies and experimental surveys among the students learning English in Bulgaria in order to facilitate their language acquisition, particularly among sports students, who have already developed and expressed their alternative Ego in the field of sport.

\section{Literature}

Clement, R., B. Kruidenier. (1983). Orientation in second language acquisition: I. The effects of ethnic TY, Milieu, and target language on their emergence. Language Learning, Vol. 33, Issue 3: 273-291

Crystal, D. (2003). English as a global language. Cambridge University Press, UK

Csizér, K. and Kormos, J. (2009). Learning experience, selves and motivated learning behaviour: A comparativeanalysis of structural models for Hungarian secondary and university learners of English. In Z. Dörnyei andE. Ushioda (Eds.), Motivation, language identity and the L2 self (pp. 98-119). Bristol: Multilingual Matters

Dimitrova, L., (2006). The effect of chess practice on the development of certain social characteristics among children and adolescents. IV National Scientific-practical Conference "Physical education and Sport at School", Varna, p. 358-389

Doncheva, L. (2012). Validation of the Bulgarian version of the Attitude/Motivation test Battery (Gardner, 1985). VI International Scientific Congress "Sport. Stress. Adaptation", Science and Art, 2012

Dörnyei, Z. (2005). The psychology of the language learner: Individual differences in second language acquisition. Mahwah, NJ: Lawrence Erlbaum.

Dörnyei, Z. (2009). The L2 motivational self system. In Z. Dörnyei \& E. Ushioda (Eds.), Motivation, language identity and the L2 self (pp. 9-42). Bristol: Multilingual Matters.

Dörnyei, Z., Csizér, K., \& Németh, N. (2006). Motivation, language attitudes and globalisation: A Hungarian perspective. Clevedon, England: Multilingual Matters

Gardner, R. C. \& Lambert, W. (1972). Attitudes and motivation in second language learning. Rowley, Mass: Newbury House Publishers, Inc.

Graddol, D. (2006). English next. London: British Council.

Guiora, A. \& Acton, W. (1979). Personality and language: A restatement. Lan-guage Learning, 29, 193-204. Guiora, A. (1972). Construct validity and transpositional research: Toward an empirical study of psychoanalytic concepts. Comprehensive Psychiatry, 13, 139-150.

Higgins, E.T. (1987). Self-discrepancy: A theory relating self and affect. Psychological Review, 94, 319-340.

Jenkins, J. (2007). English as a Lingua Franca: attitude and identity. Oxford: Oxford

Kuleva, M., (2014). Education in sports specialty through electronic forms of distance education. Proceedings Book $9^{\text {th }}$ FIEP European Congress; $7^{\text {th }}$ International Scientific Congress "Sport, Stress, Adaptation", Extra Issue, 2014

Little, D. (2004). Democracy, discourse and learner autonomy in the foreign language classroom. Utbildning \& Demokrati, 13(3), 105-126.

Markus, H., \& Nurius, P. (1986). Possible selves. American Psychologist, 41, 954-969.

Mcdonough, S. H. (1981). Psychology In Foreign Language Teaching. (2nd Ed.). London: Unwin Hyman Ltd. Meddings, L., \& Thornbury, S. (2009). Teaching unplugged: Dogme in English language teaching. Peaslake: Delta Publishing.

Rardin, J.P., Tranel, D. D., P. L. Tirone and Green, B. D. (1988). Education in a New Dimension. East Dubuque, IL: Counseling-Learning Publications.

Richards, K. (2006). 'Being the teacher': identity and classroom conversation. Applied Linguistics, 27(1), 5177.

Ryan, S. (2009). Self and identity in L2 motivation in Japan: The ideal L2 selves of Japanese learners of English. In Z. Dörnyei \& E. Ushioda (Eds.), Motivation, Language Identity and the L2 Self (pp. 120-143) Multilingual Matters

Taguchi, T., Magid, M. and Papi, M. (2009) The L2 Motivational Self System among Japanese, Chinese, and 
Iranian Learners of English: A Comparative Study. In: Ushioda, E. (2009). A person-in-context relational view Dornyei, Z. and Ushioda, E., Eds., Motivation, Language of emergent motivation, self and identity. In Z. Dörnyei Identity and the L2 Self, Multilingual Matters, Bristol, \& E. Ushioda (Eds.), Motivation, language identity and 66-97. the L2 self (pp. 215-228). Bristol: Multilingual Matters.

Thornbury, S. (2000). A dogma for EFL. IATEFL Issues, van Lier, L. (2007). Action-based teaching, Autono153 (February - March 2000), p. 2. University Press. my and Identity. Innovation in Language learning and Teaching, Vol. 1, pages: 45-65 